\title{
Natural products and hepatocellular carcinoma: a review
}

\author{
Asma M. Alnajjar ${ }^{1}$, Hussien A. Elsiesy ${ }^{1,2}$ \\ ${ }^{1}$ College of Medicine, Alfaisal University, Riyadh 11533, Saudi Arabia \\ ${ }^{2}$ Department of Liver and Small Bowel Transplantation and Hepatobiliary and Pancreatic Surgery, King Faisal Specialist Hospital and \\ Research Center, Riyadh 11211, Saudi Arabia
}

\begin{abstract}
Hepatocellular carcinoma $(\mathrm{HCC})$ is the fifth commonest cause of malignancy and the third cause of cancer mortality. There are different treatment options for HCC ranging from loco-regional therapy to surgical treatment. Different regimen of systemic chemotherapy has been tried with a poor response. Several studies aimed at discovering more molecules for the management of HCC. Those studies aimed at recognizing and targeting several signaling and molecular pathways that lead to cellular proliferation and tumor formation. In this review, we discussed the role of several agents found in natural and dietary products such as curcumin, resveratrol, flavonoids, Rubus aleaefolius Poir total alkaloids, Livistona chinensis seed, and crocetin. We had used the names of the above-mentioned products as key words in addition to "HCC" on PubMed to find studies that discussed their roles in HCC. Articles were downloaded for reviewing and discussing natural products that had adequate studies in treating HCC.
\end{abstract}

Key words: Hepatocellular carcinoma; molecular signaling; natural products

Address for correspondence:

Dr. Hussien A. Elsiesy, Department of Liver and Small Bowel Transplantation and Hepatobiliary and Pancreatic Surgery, King Faisal Specialist Hospital and Research Center, MBC 72, P. O. Box: 3354, Riyadh 11211, Saudi Arabia. E-mail: helsiesy@gmail.com

Received: 04-09-2015, Accepted: 23-09-2015

\section{INTRODUCTION}

Hepatocellular carcinoma (HCC) is the fifth commonest cause of malignancy and the third cause of cancer mortality. ${ }^{[1,2]}$ Most patients with HCC were diagnosed in advanced stage that carried poor outcome with an overall 5-year survival rate of $<9 \%{ }^{[3,4]}$ An estimation of 21,000 deaths related to HCC was reported in the US in 2012. ${ }^{[5]}$ HCC has been frequently reported in Sub-Saharan Africa, Europe, North America, and Asia. ${ }^{[6,7]}$ Most HCC occurs in the patients with liver cirrhosis mainly related to hepatitis $\mathrm{B}$ and $\mathrm{C}$ infections, hemochromatosis, non-alcoholic steatohepatitis, alcohol consumption, nitrosamines, and

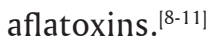

\begin{tabular}{|l|c|}
\hline \multicolumn{2}{|c|}{ Access this article online } \\
\hline \multirow{2}{*}{ Website: } & Quick Response Code \\
\hline http://www.hrjournal.net/ & \\
& DOI: \\
10.4103/2394-5079.167379 & \\
&
\end{tabular}

Hepatic carcinogens, viral hepatitis, and liver cirrhosis induce inflammation and oxidative stress. ${ }^{[12]}$ Production of free radicals (such as oxygen and nitrogen species) as well as cytokines and chemokines lead to cellular injury. ${ }^{[12]}$ Following that, cellular proliferation happens, leading to malignant transformation. ${ }^{[13,14]}$ Moreover, signaling processes at the cellular and molecular levels are involved throughout the development of HCC. ${ }^{[15-17]}$

Management of HCC is rather complex compared to other malignancy; it happens mostly in the setting of liver cirrhosis, and the treatment option largely depends on the stage of liver disease, the patient's functional status, number, size and location of tumor, and the presence or

This is an open access article distributed under the terms of the Creative Commons Attribution-NonCommercial-ShareAlike 3.0 License, which allows others to remix, tweak, and build upon the work non-commercially, as long as the author is credited and the new creations are licensed under the identical terms.

For reprints contact: reprints@medknow.com

How to cite this article: Alnajjar AM, Elsiesy HA. Natural products and hepatocellular carcinoma: a review. Hepatoma Res 2015;1:119-24. 
absence of vascular invasion. ${ }^{[18]}$ Several staging systems have been developed for HCC, but the best and most widely used is Barcelona Clinic Liver Cancer classification; added to the staging, it has prognostic and treatment implication. ${ }^{[19]}$

There are different treatment options for HCC ranging from loco-regional therapy (radiofrequency ablation, arterial chemoembolization, intra-tumor ethanol injection, yttrium-90 intra-arterial delivery as microspheres, and microwave coagulation) to surgical treatment (surgical resection and liver transplantation) and sorafenib..$^{[9,20,21]}$ Distinctive regimen of chemotherapy has been tried with poor response.

Surgical treatment is the best present-day management options for HCC, but not all patients are eligible for it. ${ }^{[12]}$ Surgical resection cannot be performed if the tumor is present in multiple sites, in advanced liver disease (Child's B and $\mathrm{C}$ ) and in the presence of vascular invasion, ${ }^{[21]}$ and only about $20 \%$ of patients are candidates for surgical resection. ${ }^{[22]}$ Early on, HCC was a contraindication for liver transplantation due to poor result. Mazzaferro et al. ${ }^{[23]}$ published Milan criteria, in which patients with early disease have a good outcome. A significant number of HCC patients do not meet Milan criteria on presentation or drop out due to disease progression while waiting for liver transplantation due to the shortage of donors. ${ }^{[23]}$ Sorafenib, a tyrosine kinase inhibitor and vascular endothelial growth factor, is presently used in managing unresected HCC. ${ }^{[24]}$ It increases the average survival time by 3 months in patients with late-stage HCC. ${ }^{[18]}$ However, sorafenib can be used in Child's A and selected Child's B patients, in addition to the side effect and high cost. ${ }^{[25,26]}$

Clearly, the available treatment option is far from optimal, either due to limited efficacy or contraindication due to advanced liver disease (resection and loco-regional therapy for Child's C), this reiterates the need for new treatment option.

Several studies aimed at discovering more molecules for the management of HCC. Those studies aimed at recognizing and targeting several signaling and molecular pathways that lead to cellular proliferation and tumor formation. ${ }^{[12,27-29]}$

In this review, we discussed the role of several agents found in natural and dietary products such as curcumin, resveratrol, flavonoids, Rubus aleaefolious Poir total alkaloids, Livistona chinensis seed, and crocetin. We had used the names of the above-mentioned products as key words in addition to "HCC" on PubMed to find studies that discussed their roles in HCC. Articles were downloaded for reviewing and discussing natural products that had adequate studies in treating HCC.

\section{CURCUMIN}

Curcumin is a polyphenol, a diferuloylmethane and it is among the three main curcuminoids present in turmeric. ${ }^{[18]}$ Curcumin is a potent anti-inflammatory agent. ${ }^{[30]}$ Curcumin has been proven to be effective in treating a variety of conditions such as allergy, psoriasis, diabetes, rheumatoid arthritis, asthma, and neurodegenerative diseases. ${ }^{[18]}$ Moreover, it is cardioprotective, hepatoprotective, carcinoprotective, and neuroprotective. ${ }^{[18]}$ As mentioned earlier, free radicals generation is an important step in tumor formation, and curcuminoids are known to inhibit oxidation owing to their methoxy group, 1,3 $\beta$-diketone moiety, and phenolic hydroxyl group. ${ }^{[31]}$ Curcumin was found to inhibit nuclear factor-kB (NF-kB), which activated inflammatory cytokines and chemokines, leading to several inflammatory conditions. ${ }^{[32-34]} \mathrm{NF}-\mathrm{kB}$ activation promotes cellular proliferation, angiogenesis, and invasion and inhibits apoptosis. ${ }^{[35,36]}$ In addition, curcumin also inhibits interleukin-1 (IL-1), IL-1B, IL-6, IL-8, tumor necrosis alpha, and cyclo-oxygenase pathways. ${ }^{[35,37-39]}$ Several studies have supported curcumin's anti-oxidant and anti-inflammatory, particularly in HCC. Dai et al. ${ }^{[27]}$ studied the anti-tumor effects of curcumin in vitro and in vivo. Curcumin inhibited HepG2's proliferation in a dose and time dependent fashion, with the most potent inhibition at a concentration of $8 \mathrm{umol} / \mathrm{L}$ for $48 \mathrm{~h}$, it leads to HepG2 induced cells apoptosis at high doses, the apoptosis rate increased up to $20 \%$ at a curcumin concentration of $16 \mathrm{umol} / \mathrm{L}$. In addition, high doses of curcumin have been shown to elevate casepase-3, an essential protein for apoptosis. ${ }^{[27]}$ Curcumin has restricted liver tumor growth in HepG2 xenograft mice models in vivo; the greatest reduction in tumor volume was around $3740 \mathrm{~mm}^{3}$ at a high curcumin dose of $60 \mathrm{mg} / \mathrm{kg} .{ }^{.27]}$ Curcumin also mediated apoptosis in HL60, SGC7901, and Bel7402 cells by inhibiting telomerase activity. ${ }^{[40]}$

In another study by Lin et al., ${ }^{\mid 41]}$ curcumin caused a decline migration and invasion of SK-Hep-1 cells as well as matrix metalloproteinase-9 (MMP-9) levels. Also, curcumin has an inhibitory effect of vasculogenic mimicry in SK-Heo-1 cells, a process in which hepatocytes act as endothelial cells and form blood vessels, by inhibiting the STAT3 and Akt pathways. ${ }^{[42]}$ Moreover, curcumin decreases caveolin-1 levels and epidermal growth factor signaling, and therefore may prevent vascular invasion and metastasis. ${ }^{[40]}$ Unfortunately, curcumin has poor pharmacokinetics as it undergoes poor 
absorption and has low bioavailability. ${ }^{[4]}$ Curcumin gets directly conjugated once it is absorbed, and only a small amount remains as free curcumin. ${ }^{[43]}$ It has been suggested that its metabolite, curcumin glucuronide, is responsible for most of its therapeutically assumed action, ${ }^{[44]}$ however, a recent study showed that curcumin glucuronide has a less potent effect than curcumin itself on HepG2 cells, as the expression of GSTT1, CAT, IL-8, AREG, and ACOX1 genes was greatly downregulated by curcumin than by curcumin glucuronide. ${ }^{|43|}$ In addition, curcumin is more rapidly absorbed than curcumin glucuronide. ${ }^{[43]}$ Curcumin is the most studied natural product for HCC; it is clearly effective in HCC at different molecular mechanisms for inflammation, proliferation, and apoptosis, there is a lack of clinical data in humans to confirm the above.

\section{RESVERATROL}

Resveratrol (3, 4', 5-trihydroxy-trans-stilbene) is found in red wine, berries, grapes, and peanuts. ${ }^{[45]}$ Resveratrol has been found to be anti-inflammatory in viral infections, neurodegenerative diseases, cardiovascular diseases, ischemia, and cancer. Resveratrol has anti-cancer effects by suppressing initiation, promotion, and progression of tumor formation. ${ }^{[46-49]}$ Moreover, it has significant anti-cancer activity by inhibiting inflammation and free radicals generation. ${ }^{[50,51]}$ Resveratrol has been found to hold rat hepatoma Fao cells and HepG2 cells in S and G2/M phase and prevent them from engaging in mitotic division. ${ }^{[52]}$ Another study showed that cells exposed to resveratrol were held in G1 phase and had an upregulation in Bax and p21 genes. ${ }^{[53]}$ It also decreased the invasion of cancer cells by downregulating hepatic growth factor. ${ }^{[54]}$ It inhibits vascular endothelial growth factor gene expression by inducing hypoxia in HepG2 cells. ${ }^{[55]}$ In another study, HepG2 cells exposed to high concentrations of resveratrol reaching between 50 and 100 umol/L for more than $48 \mathrm{~h}$ were more prone to apoptosis, in a dose-dependent fashion. ${ }^{[56]}$ In a study that exposed $\mathrm{H} 22$ cells to resveratrol with 5-fluorouracil (FU) vs. 5-FU alone; resveratrol and 5 -FU had a greater anti-cancer activity compared to 5-FU alone. ${ }^{[57]}$ Notas et al. ${ }^{[58]}$ concluded that resveratrol has an anti-proliferative effect against HepG2 cells as well as inducing the production of nitric oxide. It has also been shown to downregulate NF-kB, caveolin-1, and MMP-9. ${ }^{[59,60]}$ Several in vivo studies also support the anti-tumor activity of resveratrol in HCC. Resveratrol was administered to mice that had HCC tumor cells, hepatic tumor growth reduced and cell cycle proteins p34cdc2 and cyclin B1's expression was suppressed. ${ }^{[61]}$ Resveratrol has shown to have both in vivo and in vitro effect against HCC though different pathways and appear to have a promising potential, yet there is no clinical data in humans.

\section{FLAVONOIDS}

Flavonoids are polyphenols found in vegetables, fruits, flowers, tea, wine, stems, and roots. ${ }^{[62]}$ There are seven types of flavonoids: Anthocyanidins, flavanones, flavonols, flavones, flavanols, flavononol, and isoflavones. ${ }^{[63 \mid}$ They have been shown to be cardio-protective and hepato-protective and possess anti-viral and anti-cancer activity. ${ }^{[64-66]}$ Flavonoids have found to induce apoptosis in HepG2 cells via activation of the mitochondrial pathway, along with the translocation of cytochrome c, activation of caspases such as 9, 8, and 3, abnormal changes in mitochondrial membrane potential, generation of reactive oxygen species, elevation in intracellular calcium, and upregulated transcription of endonuclease $G$ and apoptosis inducing factor-related genes. ${ }^{[67]}$ Flavonoids have also been found to inhibit HepG2 cells growth by inhibiting the NF-kB pathway via blocking tumor necrosis factor-alpha. ${ }^{[68]}$ Administering epigallocatechin-3-gallate (EGCG), which is found in green tea, to HepG2 cells induces their apoptosis by suppressing epidermal growth factor receptor/c-Met signaling; therefore, suppress tumor cell proliferation and invasion. ${ }^{[69]}$ Quercetin, found in flavonol, has shown to restrain the expression of heat shock proteins 27 and 40, which lead to resistance to chemotherapy, hence potentiating the effect of the chemotherapeutic agent. ${ }^{[70]}$ Moreover, flavonoids have been found to be anti-hepatitis B virus (HBV) and hepatitis B core. EGCG inhibits HBV replication by altering its DNA synthesis. ${ }^{\text {[1] }}$ Furthermore, hepatitis $C$ virus is inhibited by catechin that interferes with NF-kB and COX-2 pathways. ${ }^{[72]}$

Like curcumin and resveratrol, flavonoids appear to have activity against HCC with different mechanisms, through different pathways but need to be tested in clinical trial.

\section{TOTAL ALKALOIDS OF RUBUS ALEAEFOLIOUS POIR}

$R$. aleaefolious is a plant used for the management of hepatitis in China. ${ }^{[73]}$ Hong et al. ${ }^{[74]}$ have reported that components of $R$. aleaefolious, such as butanol and ethylacetate, are hepatoprotective in mice with acute liver injury after exposure to carbon tetrachloride. Reports from the literature have discussed the protective and therapeutic role of $R$. aleaefolious Poir in carcinogenesis. ${ }^{[75,76]}$ Zhao et al. ${ }^{\mid 73]}$ examined the therapeutic effects of total alkaloids in $R$. aleaefolious Poir (TARAP) on HCC both in vitro and in vivo. TARAP has been shown to affect HCC growth and induce apoptosis in HepG2 cells via mitochondrion-mediated apoptosis by causing the loss of mitochondrion potential and activation of caspases 9 and 3, apoptosis was dose dependent. ${ }^{[73]}$ Bax and $\mathrm{Bcl}-2$ are important proteins involved in the process of apoptosis. ${ }^{[77]} \mathrm{Bcl}-2$ is known to be anti-apoptotic, ${ }^{[73]}$ and BAX 
is pro-apoptotic. ${ }^{1788}$ If the ratio of $\mathrm{Bcl}-2$ to $\mathrm{BAX}$ is great, then apoptosis does not occur. ${ }^{[73]}$ TARAP has downregulated the expression of $\mathrm{Bcl}-2$ and upregulated the expression of $\mathrm{BAX}$, decreasing the Bcl-2-BAX ratio, hence inducing apoptosis. ${ }^{[73]}$ TARAP has been used in China for hepatitis and its use in HCC needs further studies.

\section{LIVISTONA CHINENSIS SEED}

L. chinensis seed has been used in China for cancer treatment. ${ }^{[79]}$ Lin et al. ${ }^{[28]}$ have evaluated the therapeutic role of ethanol extract of the $L$. chinensis seed (EELC) against HCC both in vitro and in vivo. EELC has inhibited tumor growth in HCC xenograft mice and decreased the tumor weight by $43 \%$, moreover, EELC tumor inhibition was assessed in vitro on HepG2 cells, and the maximum reduction in cell viability was around $60 \%$ in a maximum time of $24 \mathrm{~h}$, it also induced cell apoptosis in HCC xenograft mice and HepG2 cells. ${ }^{[28]}$ Moreover, EELC has induced the loss of the mitochondrion membrane potential in HepG2 cells, leading to apoptosis and stimulates the release of caspases 9 and 3 in HepG2 cells and causes a rise in the BAX-Bcl-2 ratio, as what TARAP does. ${ }^{\mid 28]}$

\section{CROCIN}

Derived from Crocus sativus, saffron exhibits a therapeutic effect against depression, cancer, and asthma. ${ }^{[80]}$ It also acts like oxytocin and as a stimulant. ${ }^{[80]}$ Three compounds are found in saffron: Picrocrocin, crocin, and safranal. ${ }^{[81]}$ Crocins give saffron its color. ${ }^{[80]}$ Several studies discussed the anti-cancer effect of saffron in different types of cancer such as pancreatic, gastric, bladder, and hepatic cancer. ${ }^{[2-85]}$ Noureini and Wink ${ }^{[84}$ studied the anti-proliferative effects of crocin in HepG2 cells. HepG2 cells exposed to $3 \mathrm{mg} / \mathrm{mL}$ of crocin had almost a 59\% decrease in telomerase activity. In addition, crocin and safranil have shown to increase the cleavage of caspase-3, arrest the cell cycle, and cause DNA damage in HepG2 cells. ${ }^{[85]}$ Moreover, Tseng et al. ${ }^{[86]}$ reported that crocetin, a major constituent in saffron, was an anti-oxidant and hepatoprotective by decreasing the synthesis of malondialdehyde in hepatocytes, a marker for fatty acid oxidation and oxidative stress. As concluded by other researchers, crocetin protects against cancer by inducing apoptosis and arresting the cell cycle. ${ }^{[86]}$

\section{CONCLUSION}

The potential chemo-preventive and therapeutic role of above discussed natural products in HCC is due to their potent anti-oxidant and anti-inflammatory properties as well as their ability to modulate different signaling mechanisms that are implicated in the process of carcinogenesis. They hold considerable promise as therapeutic agents for HCC. Most of these studies are preclinical with very limited clinical data; therefore, the clinical efficacy of these products is still far from being tested. There is a need to develop a dosing from using the available technology to overcome the low bioavailability and to have a standard dosage for future clinical trials. Once that is achieved, the safety of these products in high doses needs to be ascertained, although they have been in use for hundreds of years.

Lack of good clinical trials testing these products compared to sorafenib and other pharmacological therapy may be due to lack of financial support to conduct such trails.

There is a pressing need for governmental funding and collaboration between centers to conduct multicenter randomized open label studies using the standard of care, with or without these products either individualized or in combination.

\section{Financial support and sponsorship}

Nil.

\section{Conflict of interest}

There is no conflict of interest.

\section{REFERENCES}

1. Schutte K, Bornschein J, Malfertheiner P. Hepatocellular carcinoma-epidemiological trends and risk factors. Dig Dis 2009;27:80-92.

2. Thun MJ, DeLancey JO, Center MM, Jemal A, Ward EM. The global burden of cancer: priorities for prevention. Carcinogenesis 2010;31:100-10.

3. Sokolowski KM, Balamurugan M, Kunnimalaiyaan S, Gamblin TC, Kunnimalaiyaan M. Notch signaling in hepatocellular carcinoma: molecular targeting in an advanced disease. Hepatoma Res 2015;1:11-8.

4. Sherman M. Hepatocellular carcinoma: epidemiology, risk factors, and screening. Semin Liver Dis 2005;25:143-54.

5. Siegel R, Naishadham D, Jemal A. Cancer statistics, 2012. CA Cancer J Clin 2012;62:10-29.

6. Jemal A, Bray F, Center MM, Ferlay J, Ward E, Forman D. Global cancer statistics. CA Cancer J Clin 2011;61:69-90.

7. Chen J. Trends in the incidence of liver cancer and its primary prevention in China. Chin J Clin Hepatol 2012;4:256-60.

8. Bartsch H, Montesano R. Relevance of nitrosamines to human cancer. Carcinogenesis 1984;5:1381-93.

9. Okuda K. Hepatocellular carcinoma. J Hepatol 2000;32:225-37.

10. Bruix J, Llovet JM. Hepatis B virus and hepatocellular carcinoma. J Hepatol 2003;39:S59-63.

11. Kensler TW, Egner PA, Wang JB, Zhu YR, Zhang BC, Lu PX, Chen JG, Qian GS, Kuang SY, Jackson PE, Gange SJ, Jacobson LP, Muñoz A, Groopman JD. Chemoprevention of hepatocellular carcinoma in aflatoxin endemic areas. Gastroenterology 2004;127:S310-8.

12. Darvesh AS, Bishayee A. Chemopreventive and therapeutic potential of tea polyphenols in hepatocellular cancer. Nutr Cancer 2013;65:329-44.

13. Ha HL, Shin HJ, Feitelson MA, Yu DY. Oxidative stress and anti-oxidants in hepatic pathogenesis. World J Gastroenterol 2010;16:6035-43. 
14. Klaunig JE, Kamendulis LM. The role of oxidative stress in carcinogenesis. Annu Rev Pharmacol Toxicol 2004;44:239-67.

15. Pang R, Tse E, Poon RT. Molecular pathways in hepatocellular carcinoma. Cancer Lett 2006;240:157-69.

16. Wong CM, Ng IO. Molecular pathogenesis of hepatocellular carcinoma. Liver Int 2008;28:160-74.

17. Frau M, Biasi F, Feo F, Pascale RM. Prognostic markers and putative therapeutic targets for hepatocellular carcinoma. Mol Aspects Med 2010;31:179-93.

18. Darvesh AS, Aggarwal BB, Bishayee A. Curcumin and liver cancer: a review. Curr Pharm Biotechnol 2012;13:218-28.

19. Lee JH, Kim HY, Kim YJ, Yoon JH, Chung JW, Lee HS. Barcelona Clinic Liver Cancer staging system and survival of untreated hepatocellular carcinoma in a hepatitis B virus endemic area. J Gastroenterol Hepatol 2015;30:696-705.

20. Takayasu K, Muramatsu Y, Moriyama N, Hasegawa H, Makuuchi M, Okazaki N, Hirohashi S, Tsugane S. Clinical and radiologic assessments of the results of hepatectomy for small hepatocellular carcinoma and therapeutic arterial embolization for postoperative recurrence. Cancer 1989;64:1848-52

21. Sato M, Watanabe Y, Ueda S, Iseki S, Abe Y, Sato N, Kimura S, Okubo K, Onji M. Microwave coagulation therapy for hepatocellular carcinoma. Gastroenterology 1996;110:1507-14.

22. Llovet JM, Burroughs A, Bruix J. Hepatocellular carcinoma. Lancet 2003;362:1907-17.

23. Mazzaferro V, Regalia E, Doci R, Andreola S, Pulvirenti A, Bozzetti F, Montalto F, Ammatuna M, Morabito A, Gennari L. Liver transplantation for the treatment of small hepatocellular carcinomas in patients with cirrhosis. N Engl J Med 1996;334:693-9.

24. Llovet JM, Ricci S, Mazzaferro V, Hilgard P, Gane E, Blanc JF, de Oliveira AC, Santoro A, Raoul JL, Forner A, Schwartz M, Porta C, Zeuzem S, Bolondi L, Greten TF, Galle PR, Seitz JF, Borbath I, Häussinger D, Giannaris T, Shan M, Moscovici M, Voliotis D, Bruix J; SHARP Investigators Study Group. Sorafenib in advanced hepatocellular carcinoma. N Engl J Med 2008;359:378-90.

25. Je Y, Schutz FA, Choueiri TK. Risk of bleeding with vascular endothelial growth factor receptor tyrosine-kinase inhibitors sunitinib and sorafenib: a systematic review and meta-analysis of clinical trials. Lancet Oncol 2009;10:967-74.

26. Lu SC. Where are we in the chemoprevention of hepatocellular carcinoma? Hepatology 2010;51:734-6.

27. Dai XZ, Yin HT, Sun LF, Hu X, Zhou C, Zhou Y, Zhang W, Huang XE, Li XC. Potential therapeutic efficacy of curcumin in liver cancer. Asian Pac J Cancer Prev 2013;14:3855-9.

28. Lin W, Zhao J, Cao Z, Zhuang Q, Zheng L, Cai Q, Chen D, Wang L, Hong Z, Peng J. Livistona chinensis seed suppresses hepatocellular carcinoma growth through promotion of mitochondrial-dependent apoptosis. Oncol Rep 2013;29:1859-66.

29. Xia JF, Gao JJ, Inagaki Y, Kokudo N, Nakata M, Tang W. Flavonoids as potential anti-hepatocellular carcinoma agents: recent approaches using HepG2 cell line. Drug Discov Ther 2013;7:1-8.

30. Aggarwal BB, Harikumar KB. Potential therapeutic effects of curcumin, the anti-inflammatory agent, against neurodegenerative, cardiovascular, pulmonary, metabolic, autoimmune and neoplastic diseases. Int $J$ Biochem Cell Biol 2009;41:40-59.

31. Sugiyama Y, Kawakishi S, Osawa T. Involvement of the beta-diketone moiety in the anti-oxidative mechanism of tetrahydrocurcumin. Biochem Pharmacol 1996;52:519-25.

32. Singh S, Aggarwal BB. Activation of transcription factor NF-kappa B is suppressed by curcumin (diferuloylmethane) [corrected]. J Biol Chem 1995;270:24995-5000.

33. Libby P. Inflammatory mechanisms: the molecular basis of inflammation and disease. Nutr Rev 2007;65:S140-6.

34. Ralhan R, Pandey MK, Aggarwal BB. Nuclear factor-kappa B links carcinogenic and chemopreventive agents. Front Biosci (Schol Ed) 2009; 1:45-60.

35. ShishodiaS,AminHM,Lai R,AggarwalBB.Curcumin(diferuloylmethane) inhibits constitutive NF-kappaB activation, induces G1/S arrest, suppresses proliferation, and induces apoptosis in mantle cell lymphoma. Biochem Pharmacol 2005;70:700-13.

36. Kamat AM, Sethi G, Aggarwal BB. Curcumin potentiates the apoptotic effects of chemotherapeutic agents and cytokines through down-regulation of nuclear factor-kappaB and nuclear factor-kappaB-regulated gene products in IFN-alpha-sensitive and IFN-alpha-resistant human bladder cancer cells. Mol Cancer Ther 2007;6:1022-30.

37. Li L, Aggarwal BB, Shishodia S, Abbruzzese J, Kurzrock R. Nuclear factor-kappaB and IkappaB kinase are constitutively active in human pancreatic cells, and their down-regulation by curcumin (diferuloylmethane) is associated with the suppression of proliferation and the induction of apoptosis. Cancer 2004;101:2351-62.

38. Shakibaei M, Schulze-Tanzil G, John T, Mobasheri A. Curcumin protects human chondrocytes from IL-11beta-induced inhibition of collagen type II and beta1-integrin expression and activation of caspase-3: an immunomorphological study. Ann Anat 2005;187:487-97.

39. Skommer J, Wlodkowic D, Pelkonen J. Gene-expression profiling during curcumin-induced apoptosis reveals downregulation of CXCR4. Exp Hematol 2007;35:84-95.

40. Wang S, Yu S, Shi W, Ge L, Yu X, Fan J, Zhang J. Curcumin inhibits the migration and invasion of mouse hepatoma Hca-F cells through down-regulating caveolin-1 expression and epidermal growth factor receptor signaling. IUBMB Life 2011;63:775-82.

41. Lin LI, Ke YF, Ko YC, Lin JK. Curcumin inhibits SK-Hep-1 hepatocellular carcinoma cell invasion in vitro and suppresses matrix metalloproteinase-9 secretion. Oncology 1998;55:349-53.

42. Chiablaem K, Lirdprapamongkol K, Keeratichamroen S, Surarit R, Svasti J. Curcumin suppresses vasculogenic mimicry capacity of hepatocellular carcinoma cells through STAT3 and PI3K/AKT inhibition. Anti-cancer Res 2014;34:1857-64.

43. Shoji M, Nakagawa K, Watanabe A, Tsuduki T, Yamada T, Kuwahara S, Kimura F, Miyazawa T. Comparison of the effects of curcumin and curcumin glucuronide in human hepatocellular carcinoma HepG2 cells. Food Chem 2014;151:126-32.

44. Bandyopadhyay D. Farmer to pharmacist: curcumin as an anti-invasive and anti-metastatic agent for the treatment of cancer. Front Chem 2014;2:113.

45. Bishayee A, Politis T, Darvesh AS. Resveratrol in the chemoprevention and treatment of hepatocellular carcinoma. Cancer Treat Rev 2010;36:43-53.

46. Baur JA, Sinclair DA. Therapeutic potential of resveratrol: the in vivo evidence. Nat Rev Drug Discov 2006;5:493-506.

47. Udenigwe CC, Ramprasath VR, Aluko RE, Jones PJ. Potential of resveratrol in anti-cancer and anti-inflammatory therapy. Nutr Rev 2008;66:445-54.

48. Saiko P, Szakmary A, Jaeger W, Szekeres T. Resveratrol and its analogs: defense against cancer, coronary disease and neurodegenerative maladies or just a fad? Mutat Res 2008;658:68-94.

49. Shankar S, Singh G, Srivastava RK. Chemoprevention by resveratrol: molecular mechanisms and therapeutic potential. Front Biosci 2007; 12:4839-54.

50. Das S, Das DK. Anti-inflammatory responses of resveratrol. Inflamm Allergy Drug Targets 2007;6:168-73.

51. Rubiolo JA, Mithieux G, Vega FV. Resveratrol protects primary rat hepatocytes against oxidative stress damage: activation of the Nrf2 transcription factor and augmented activities of anti-oxidant enzymes. Eur J Pharmacol 2008;591:66-72.

52. Delmas D, Jannin B, Cherkaoui Malki M, Latruffe N. Inhibitory effect of resveratrol on the proliferation of human and rat hepatic derived cell lines. Oncol Rep 2000;7:847-52. 
53. Kuo PL, Chiang LC, Lin CC. Resveratrol-induced apoptosis is mediated by p53-dependent pathway in Hep G2 cells. Life Sci 2002;72:23-34.

54. De Ledinghen V, Monvoisin A, Neaud V, Krisa S, Payrastre B, Bedin C, Desmoulière A, Bioulac-Sage P, Rosenbaum J. Trans-resveratrol, a grapevine-derived polyphenol, blocks hepatocyte growth factor-induced invasion of hepatocellular carcinoma cells. Int J Oncol 2001;19:83-8.

55. Zhang Q, Tang X, Lu QY, Zhang ZF, Brown J, Le AD. Resveratrol inhibits hypoxia-induced accumulation of hypoxia-inducible factor-1alpha and VEGF expression in human tongue squamous cell carcinoma and hepatoma cells. Mol Cancer Ther 2005;4:1465-74.

56. Kocsis Z, Marcsek ZL, Jakab MG, Szende B, Tompa A. Chemopreventive properties of trans-resveratrol against the cytotoxicity of chloroacetanilide herbicides in vitro. Int J Hyg Environ Health 2005;208:211-8.

57. Sun Z, Pan C, Liu H, Wang G. Anti-hepatoma activity of resveratrol in vitro. World J Gastroenterol 2002;8:79-81.

58. Notas G, Nifli AP, Kampa M, Vercauteren J, Kouroumalis E, Castanas E. Resveratrol exerts its anti-proliferative effect on HepG2 hepatocellular carcinoma cells, by inducing cell cycle arrest, and NOS activation. Biochim Biophys Acta 2006;1760:1657-66.

59. Yu H, Pan C, Zhao S, Wang Z, Zhang H, Wu W. Resveratrol inhibits tumor necrosis factor-alpha-mediated matrix metalloproteinase- 9 expression and invasion of human hepatocellular carcinoma cells. Biomed Pharmacother 2008;62:366-72.

60. Yerian LM, Anders RA, Tretiakova M, Hart J. Caveolin and thrombospondin expression during hepatocellular carcinogenesis. Am J Surg Pathol 2004;28:357-64.

61. Yu L, Sun ZJ, Wu SL, Pan CE. Effect of resveratrol on cell cycle proteins in murine transplantable liver cancer. World J Gastroenterol 2003;9:2341-3

62. Nijveldt RJ, van Nood E, van Hoorn DE, Boelens PG, van Norren K, van Leeuwen PA. Flavonoids: a review of probable mechanisms of action and potential applications. Am J Clin Nutr 2001;74:418-25.

63. Ververidis F, Trantas E, Douglas C, Vollmer G, Kretzschmar G, Panopoulos N. Biotechnology of flavonoids and other phenylpropanoid-derived natural products. Part I: chemical diversity, impacts on plant biology and human health. Biotechnol J2007;2:1214-34.

64. Cui X, Wang Y, Kokudo N, Fang D, Tang W. Traditional Chinese medicine and related active compounds against hepatitis $\mathrm{B}$ virus infection. Biosci Trends 2010;4:39-47.

65. Handoussa H, Osmanova N, Ayoub N, Mahran L. Spicatic acid: a 4-carboxygentisic acid from Gentiana spicata extract with potential hepatoprotective activity. Drug Discov Ther 2009;3:278-86.

66. Abdel-Salam OM, Youness ER, Mohammed NA, Abd-Elmoniem M, Omara E, Sleem AA. Neuroprotective and hepatoprotective effects of micronized purified flavonoid fraction (Daflon(R)) in lipopolysaccharide-treated rats. Drug Discov Ther 2012;6:306-14.

67. Jiang CP, Ding H, Shi DH, Wang YR, Li EG, Wu JH. Pro-apoptotic effects of tectorigenin on human hepatocellular carcinoma HepG2 cells. World J Gastroenterol 2012;18:1753-64.

68. Dorn C, Kraus B, Motyl M, Weiss TS, Gehrig M, Scholmerich J, Heilmann J, Hellerbrand C. Xanthohumol, a chalcon derived from hops, inhibits hepatic inflammation and fibrosis. Mol Nutr Food Res 2010;54:S205-13

69. Jin J, Chang Y, Wei W, He YF, Hu SS, Wang D, Wu YJ. Prostanoid EP1 receptor as the target of (-)-epigallocatechin-3-gallate in suppressing hepatocellular carcinoma cells in vitro. Acta Pharmacol Sin 2012;33:701-9.
70. Sharma A, Upadhyay AK, Bhat MK. Inhibition of Hsp27 and Hsp40 potentiates 5-fluorouracil and carboplatin mediated cell killing in hepatoma cells. Cancer Biol Ther 2009;8:2106-13.

71. He W, Li LX, Liao QJ, Liu CL, Chen XL. Epigallocatechin gallate inhibits HBV DNA synthesis in a viral replication - Inducible cell line. World J Gastroenterol 2011;17:1507-14.

72. Lee JC, Tseng CK, Wu SF, Chang FR, Chiu CC, Wu YC. San-Huang-Xie-Xin-Tang extract suppresses hepatitis $\mathrm{C}$ virus replication and virus-induced cyclooxygenase-2 expression. $J$ Viral Hepat 2011;18:e315-24.

73. Zhao J, Chen X, Lin W, Wu G, Zhuang Q, Zhong X, Hong Z, Peng J. Total alkaloids of Rubus aleaefolius Poir inhibit hepatocellular carcinoma growth in vivo and in vitro via activation of mitochondrial-dependent apoptosis. Int J Oncol 2013;42:971-8.

74. Hong Z, Chen W, Zhao J, Wu Z, Zhou J, Li T, Hu J. Hepatoprotective effects of Rubus aleaefolius Poir and identification of its active constituents. J Ethnopharmacol 2010;129:267-72.

75. Xue H, Aziz RM, Sun N, Cassady JM, Kamendulis LM, Xu Y, Stoner GD, Klaunig JE. Inhibition of cellular transformation by berry extracts. Carcinogenesis 2001;22:351-6.

76. Lee JH, Ham YA, Choi SH, Im EO, Jung JH, Im KS, Kim DK, Xu Y, Wang MW, Kim ND. Activity of crude extract of Rubus crataegifolius roots as a potent apoptosis inducer and DNA topoisomerase I inhibitor. Arch Pharm Res 2000;23:338-43.

77. Borner C. The Bcl-2 protein family: sensors and checkpoints for life-or-death decisions. Mol Immunol 2003;39:615-47.

78. Ow YP, Green DR, Hao Z, Mak TW. Cytochrome c: functions beyond respiration. Nat Rev Mol Cell Biol 2008;9:532-42.

79. Zhao G, Dai S, Chen R. Dictionary of traditional Chinese medicine. Shanghai: Shanghai Scientific and Technical Publishers; 2006. p. 2459-60.

80. Bolhassani A, Khavari A, Bathaie SZ. Saffron and natural carotenoids: biochemical activities and anti-tumor effects. Biochim Biophys Acta 2014;1845:20-30

81. Bakshi H, Sam S, Rozati R, Sultan P, Islam T, Rathore B, Lone Z, Sharma M, Triphati J, Saxena RC. DNA fragmentation and cell cycle arrest: a hallmark of apoptosis induced by crocin from Kashmiri saffron in a human pancreatic cancer cell line. Asian Pac J Cancer Prev 2010;11:675-9.

82. Bathaie SZ, Miri H, Mohagheghi MA, Mokhtari-Dizaji M, Shahbazfar AA, Hasanzadeh H. Saffron aqueous extract inhibits the chemically-induced gastric cancer progression in the wistar albino rat. Iran J Basic Med Sci 2013;16:27-38.

83. Sun Y, Xu HJ, Zhao YX, Wang LZ, Sun LR, Wang Z, Sun XF. Crocin exhibits anti-tumor effects on human leukemia HL-60 cells in vitro and in vivo. Evid Based Complement Alternat Med 2013;2013:690164

84. Noureini SK, Wink M. Anti-proliferative effects of crocin in HepG2 cells by telomerase inhibition and hTERT down-regulation. Asian Pac J Cancer Prev 2012;13:2305-9.

85. Li CY, Huang WF, Wang QL, Wang F, Cai E, Hu B, Du JC, Wang J, Chen R, Cai XJ, Feng J, Li HH. Crocetin induces cytotoxicity in colon cancer cells via p53-independent mechanisms. Asian Pac J Cancer Prev 2012;13:3757-61.

86. Tseng TH, Chu CY, Huang JM, Shiow SJ, Wang CJ. Crocetin protects against oxidative damage in rat primary hepatocytes. Cancer Lett 1995;97:61-7. 